\title{
Design and Analysis of Luffa Fiber Natural Composite-Foam Core Sandwich for Aerospace Application
}

\author{
${ }^{1}$ Dr.R.Arravind, ${ }^{2}$ S.Dino Britto, ${ }^{3}$ P.Jayaprakash, ${ }^{4}$ K.Ravikumar \\ ${ }^{1,2,3,4}$ Department of Aeronautical Engineering, Paavai Engineering College, Namakkal-637018.
}

\begin{abstract}
A Sandwich structure is a type of composite consists of two or more separated components with different material properties, which together constitute a high performance material. The sandwich structure has a discrete structure in which the base material is glued and covered with a surface material. The material has high compressive and shear strength. When bounded to each other, this combination provides a high flexural modulus of the sandwich structure. Here a Luffa fiber and epoxy resin natural composite using compression moulding is fabricated to find the mechanical properties of a composite laminate. As per ASTM standard UTM tests and point bending test conducted to assess the tensile and bending strength. A sandwich structure is fabricated using luffa fiber natural composite as a face materials and polyurethane foam as a core. The sandwich structures are tested for its bending and shear strengths as per the ASTM standards. The experimental results are validated using the Numerical analysis done by ANSYS. The results are more favorable for the aircraft applications.
\end{abstract}

\section{INTRODUCTION}

A sandwich type is one tpes of composite material. A Sandwich structure usually made up of double twin slender,rigid and strong plates of composite material or metallic material divided by comparatively softcore.Front and core are combined to design an efficient load carrying assembly. Lightweight sandwich structure is used to raise the specific stiffness, which formulate a strengthening the development structure. The face carries tensile and compressive stresses, the core support both side force and the shear stress. The principle of sandwich composite is developed well in a fields of shipbuilding and aerospace technology.Today, sandwich panels can be used in many other technological areas such as high-speed trains, shipbuilding construction or automobile. Especially in shipbuilding there is strong tendency to use multilayer shells in a structure of hull.

\section{LUFFA FIBER PROPERTIES}

Luffa has a density of 0.56 to $0.92 \mathrm{~g} / \mathrm{cm}^{3}$, an average diameter of $270 \mu \mathrm{m}$, and a fine fiber angle of about $12^{\circ} .63$ percent cellulose, 20.88 percent hemicellulose, 11.69 percent lignin, and 0.4 percent ash make up the chemical composition of luffa. It should be noted that luffa is not only used as a vegetable , herbal medicine, military filters and shock absorbers all use it.

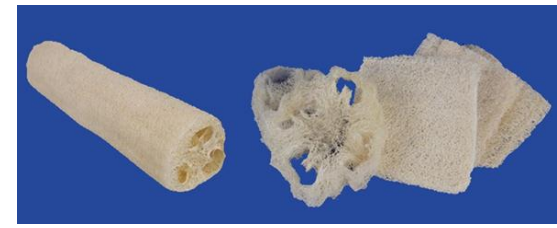

Figure 2.1 Luffa and its internal structure.

The tensile test specimens are obtained from the composite plate using the water jet cutting techniques.

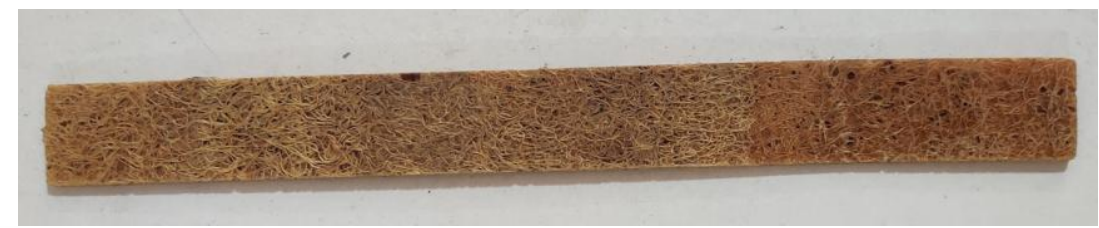

Figure-2.2 Luffa fiber- epoxy composite test specimen 


\section{International Advanced Research Journal in Science, Engineering and Technology}

Vol. 8, Issue 5, May 2021

DOI: $10.17148 /$ IARJSET.2021.8582

\section{EXPERIMENTATION}

The prepared luffa fiber natural composite tested for its mechanical properties as per the ASTM standards. Tensile tests are carried out in a computerized Universal Testing Machine ASTM D3039-76 are shown in figure 3.1. The sample was used with dimensions of $300 \mathrm{~mm}$ in length and $25 \mathrm{~mm}$ in width. The test was performed with a $10 \mathrm{~kg}$ load cell and a bonding speed of $5 \mathrm{~mm} / \mathrm{min}$. Three samples were used and the average recorded

Figure 3.1- Tensile testing of luffa fiber composite.

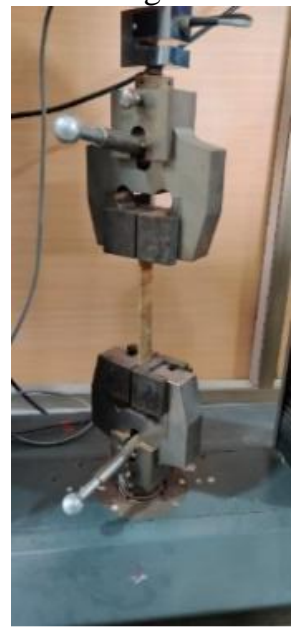

\section{RESULT AND DISCUSSION}

\subsection{TENSION TEST ON COMPOSITE FACING}

Type of specimen $=$ Rectangular bar

Initial gauge length of the specimen $=442 \mathrm{~mm}$

Width of the specimen $=70 \mathrm{~mm}$

Thickness of the specimen $=1.8 \mathrm{~mm}$

Final gauge length of the specimen $=445 \mathrm{~mm}$

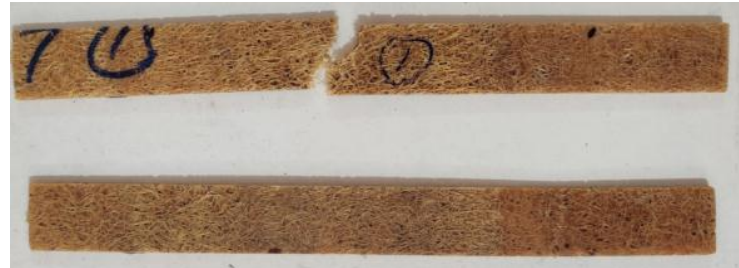

Figure-4.1 Tensile specimen before and after the test

Table 4.1 Test results

\begin{tabular}{|c|c|c|c|c|}
\hline Specimen No & $\begin{array}{c}\text { Young's Modulus } \\
(\mathrm{E}) \mathrm{MPa}\end{array}$ & $\begin{array}{c}\text { Failure load } \\
(\mathrm{N})\end{array}$ & $\begin{array}{c}\text { Max. Stress } \\
(\mathrm{MPa})\end{array}$ & $\begin{array}{c}\text { Strain at } \\
\text { Failure \% }\end{array}$ \\
\hline 1 & 339 & 585 & 7.8 & 1.6 \\
\hline 2 & 535 & 780 & 10.4 & 2.3 \\
\hline
\end{tabular}

\subsection{BENDING TEST - SANDWICH SPECIMEN}

Where

$$
\delta=\frac{P L^{3}}{24 b t_{c}^{2} t_{f} E_{f}}
$$

b-The sandwich specimen's width

$\mathrm{t}_{\mathrm{f}}$-The fiber's thickness

$t_{c}-$ The core's thickness

$E_{f}-$ Young's modulus of the fiber 


\section{International Advanced Research Journal in Science, Engineering and Technology}

Vol. 8, Issue 5, May 2021

DOI: $10.17148 / I A R J S E T .2021 .8582$

Table 4.2. 3 point bending test results.

\begin{tabular}{|c|c|c|c|}
\hline S. No & $\begin{array}{l}\text { Weights } \\
\text { (grams) }\end{array}$ & $\begin{array}{c}\text { Experimental } \\
\text { Deflection (mm) }\end{array}$ & $\begin{array}{c}\text { Theoretical } \\
\text { Deflection }(\mathrm{mm})\end{array}$ \\
\hline 1 & 50 & 0.92 & 0.82 \\
\hline 2 & 100 & 2.12 & 1.93 \\
\hline 3 & 150 & 3.42 & 3.10 \\
\hline 4 & 200 & 5.25 & 4.92 \\
\hline 5 & 250 & 7.08 & 6.85 \\
\hline 6 & 300 & 9.15 & 8.74 \\
\hline & & $\begin{array}{c}\text { Average Deflection } \\
=4.65 \mathrm{~mm}\end{array}$ & $\begin{array}{l}\text { Average Deflection } \\
\quad=4.39 \mathrm{~mm}\end{array}$ \\
\hline
\end{tabular}

\section{NUMERICAL ANALYSIS}

\subsection{Finite Element Analysis}

The sandwich panel being analyzed has a Polyurethane core with Young`s modulus is $25 \mathrm{Mpa}$ and Poisson's ratio is 0.28 . The other hand, an face materials were 6 plies of luffa fibre reinforced epoxy resin with the modulus of elasticity is $3.4 \mathrm{GPa}$ and Poisson`s ratio is 0.37 .

In the case of 3-point bending test, a 3-D model was constructed with the dimensions of $440 \times 30 \times 12.6 \mathrm{~mm}$.

Solid - Brick node 45

Facing material thickness $(6 \mathrm{ply})=3.6 \mathrm{~mm}$

Thickness of core material $=9 \mathrm{~mm}$

Facing material has orthotropic property

Core material has Isotropic property

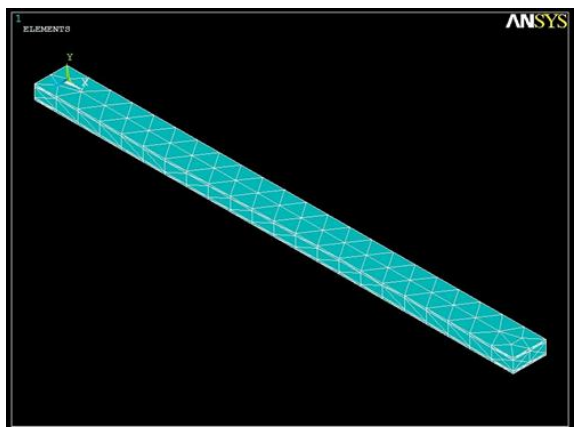

5.2 Results of experiments

Figure-5.1 3-D meshed model of sandwich panel

\section{3-point bending test simulation}

Table-5.1 Deflection result in 3 - Point bending

\begin{tabular}{|c|c|c|c|c|}
\hline S. No & $\begin{array}{l}\text { Weights } \\
\text { (grams) }\end{array}$ & $\begin{array}{l}\text { Experimental } \\
\text { Deflection }(\mathbf{m m})\end{array}$ & $\begin{array}{l}\text { Theoretical } \\
\text { Deflection (mm) }\end{array}$ & $\begin{array}{l}\text { Numerical } \\
\text { Deflection (mm) }\end{array}$ \\
\hline 1 & 50 & 0.92 & 0.82 & 1.31 \\
\hline 2 & 100 & 2.12 & 1.93 & 2.42 \\
\hline 3 & 150 & 3.42 & 3.1 & 3.73 \\
\hline 4 & 200 & 5.25 & 4.92 & 5.43 \\
\hline 5 & 250 & 7.08 & 6.85 & 7.25 \\
\hline 6 & 300 & 9.15 & 8.74 & 9.35 \\
\hline
\end{tabular}

\section{CONCLUSION}

Foam core Sandwich composite with facing made up of natural Luffa fiber / epoxy ais investigated experimentally and numerically. The composite facing and sandwich panel is manufactured by using compression molding method. Material properties of the composite facing are obtained analytically by using micro-mechanics approach.

The experimental results are close to the expected theoretical results for all test specimens. There are may be a variety explanations for other minor variations in the experimental results. 


\section{International Advanced Research Journal in Science, Engineering and Technology}

Vol. 8, Issue 5, May 2021

DOI: $10.17148 /$ IARJSET.2021.8582

Finally, the finding and research on the subject were accurate when the experimental result were compared to the theoretical results.

\section{REFERENCES}

1. "Light Weight Sandwich Construction" by J.M.Davies

2. "Mechanics of composite materials" Second edition 1999 by Jones

3. "Engineering composite materials" by Harries, B (1999)

4. "Mechanics and analysis of fabric composites and structures" Evgeny V. Morozov Autex Research Journal, Vol. 4, No2, June 2004

5. "A new hybrid concept for sandwich structures"by A.G. Mamalis a,*, K.N. Spentzas b, N.G. Pantelelish b, D.E Manolaks a, M.B. Loannidis Laboratory of Manufacturing Technology,Nataional Technical University of Athens may 2007

6. Zenkert D. "An introduction to sandwich construction” London, UK: Chameleon Press Ltd.; 1995.

7. "Failure of sandwich structures with sub-interface damage" Andrey Shipsha, Sweden.

8. "Numerical analysis of woven fabric composites lubricated spherical plain bearing." by Kewei Li, Xue Jin Shen, Youguang Chen, Shanghai 200031,China.

9. “A Comparison of FRP-Sandwich penetrating Impact test method" by Martin Hildebrand , Finland 1996.

10. Yeditepe university engineering faculty mechanical engineering laboratory, "Three point bending test"

11. "Introduction to tensile testing" source: www.asminternational.org/bookstore 